\section{Spathe Color Variation in Anthurium andraeanum Hort. and Its Relationship to Vacuolar pH}

\author{
Omaira Avila-Rostant, Adrian M. Lennon, \\ and Pathmanathan Umaharan ${ }^{1}$ \\ Department of Life Sciences, Faculty of Science and Agriculture, The University \\ of the West Indies, St. Augustine Campus, College Road, Republic of Trinidad \\ and Tobago
}

Additional index words. anthocyanin, chromospectrometry, flavonoids, flower color, phenyl propanoid pathway

\begin{abstract}
The relationship between vacuolar $\mathrm{pH}$ in Anthurium andraeanum (Hort.) and spathe color, cultivar, developmental stage, spathe location, spathe surface differences, and time after harvest was investigated with the overall long-term objective of developing a methodology for engineering blue-colored spathes. Chromospectral analysis of the pigmentation was also studied. Six experiments were conducted involving 23 cultivars of anthurium with each experiment arranged in a randomized complete block design with five replications. Spathe color was associated with vacuolar $\mathrm{pH}$ with the whites and greens having the highest pH (average 5.65) followed by corals (5.38), pinks (5.20), reds (5.10), and oranges (4.5). In general, there was correspondence between the lightness of the pigmentation $\left(\mathrm{L}^{*}\right)$ and the $\mathrm{pH}$ values with the lighter colors having higher $\mathrm{pH}$ values. There were, however, significant differences among cultivars within the color groups. Whereas spathe $\mathrm{pH}$ decreased with aging, there was no difference in the spectral data, suggesting that factors other than anthocyanin content may be contributing to the pH difference. There were no differences in $\mathrm{pH}$ between locations sampled on the spathe nor between the spathe surfaces provided there were no differences in color intensity $\left(\mathrm{L}^{*}\right)$. The $\mathrm{pH}$ increased with vase life in two of three cultivars tested with $\mathrm{pH}$ values showing an association with increases in $\mathrm{a}^{\text {* }}$ and $b^{*}$ (chromospectral data) reflecting a bluing effect. The importance of the results to engineering blue-colored spathes in anthurium is discussed.
\end{abstract}

Flower color in plants is determined by pigments such as aurones, anthocyanins, and carotenoids (Davis and Schwinn, 1997; Schijlen et al., 2004). Anthocyanins, the major pigment in Anthurium andraeanum (Hort), are the product of flavonoid biosynthesis and are divided into cyanidins and their derivatives that produce colors ranging from red to purple (Griesbach, 1996); pelargonidins and their derivatives that produce colors ranging from coral to orange (Iwata et al., 1979); and delphinidins and their derivatives that produce colors from blue to deep red (Asen and Siegelman, 1957).

Researchers have stated that the ultimate color displayed is dependent not only on the pigment present, but also on a number of factors including cell shape (Noda et al., 1994), presence of various metal ions (Shoji et al., 2007), stacking of anthocyanins with copigments such as flavones and flavonols (Goto and Kondo, 1991), and pH (Harborne, 1988; Katsumoto et al., 2007; Stewart et al., 1975). As a result, in some species, the flower color is not corre-

Received for publication 24 June 2010. Accepted for publication 23 Sept. 2010

This study was funded by a research grant from the Government of Trinidad and Tobago.

We thank the management and staff of Kairi Blooms Farm for providing the material for the research

${ }^{1}$ To whom reprint requests should be addressed; e-mail pumaharan@sta.uwi.edu. nopsis pulcherrima, blue-flowered cultivars had a $\mathrm{pH}$ more alkaline $(\mathrm{pH}$ 5.7) compared with the purple form of the species $(\mathrm{pH} 4.9)$ with high $\mathrm{pH}$ being governed by a single recessive gene (Griesbach, 1997).

Although roses exhibit a variety of colors, they lack blues. Early attempts to generate blues in roses through the introduction of the flavonoid $3^{\prime}, 5^{\prime}$-hydroxylase $\left(\mathrm{F}^{\prime} 5^{\prime} \mathrm{H}\right)$ gene were unsuccessful. Katsumoto et al. (2007) generated blue roses by placing the $\mathrm{F}^{\prime} 5^{\prime} \mathrm{H}$ gene into a genetic background with higher vacuolar $\mathrm{pH}$ and high flavonol content. Griesbach (2005) observed that although flavonols and an appropriate $\mathrm{pH}$ are important in obtaining blue orchids, the more important of the two factors was vacuolar $\mathrm{pH}$. Creation of blue orchids, he suggested, would therefore require the screening of germplasm for high floral $\mathrm{pH}$ and combining the independent codominantly inherited high $\mathrm{pH}$ genes into a single genotype (Griesbach, 2005).

Anthurium andraeanum Linden ex André is a tropical ornamental species with a limited range of spathe colors based on anthocyanin pigments that vary from orange to red. The color range has been expanded through interspecific hybridization with species belonging to the section Calomystrium (Kamemoto and Kuehnle, 1996) through the creation of a species complex referred to as $A$. andraeanum (Hort.).

Iwata et al. (1979) reported that the major spathe colors, red to pink and orange to coral, are determined by two anthocyanins, pelargonidin 3-rutinoside (pelargonidin 3-rhamonsylglucoside) and cyanidin 3-rutinoside (cyanidin 3-rhamnosyl glucoside) found exclusively in the hypodermal layers of abaxial and adaxial surfaces of the spathe (Ehrenberger and Kuehnle, 2003; Higaki et al., 1984). Whereas pelargonidin 3-rutinoside is responsible for orange and coral spathes, both pelargonidin 3 -rutinoside and cyanidin 3-rutinoside are found in red and pink spathes. Coral and pink spathes have lower concentrations of anthocyanins in comparison with orange and red counterparts (Iwata et al., 1985). The white spathes lack both anthocyanins but contain colorless flavone C-glycosides (Williams et al., 1981). Conspicuous lack of delphinidins or peonidin (a cyanidin derivative) account for the lack of mauves, purples, and blues (Iwata et al., 1985).

Recently the genetics and biochemistry of the anthurium flavonoid biosynthetic pathway have been characterized with the intention of creating colors in the blue range (Collette et al., 2004; Elibox and Umaharan, 2008a). However, no studies exist with regard to variation in $\mathrm{pH}$ in anthurium cultivars. With the objective of identifying suitable candidates for transformation toward generating blues in anthurium, this study investigates the relationship between epidermal vacuolar $\mathrm{pH}$ and a number of plant factors, including cultivar, spathe color, developmental stage of the spathe, location of anthocyanin within the spathe, differences between the abaxial and adaxial surfaces, and postharvest changes.

\section{Materials and Methods}

Plant material. Spathes were collected from 23 cultivars of Anthurium andraeanum (Hort.) maintained at Kairi Blooms Ltd., a commercial anthurium farm situated in Carapo Village, Arima, Trinidad. The collected 
samples were placed in a cooler and transported to the laboratory. All blooms were harvested between 0700 to 0800 HR during the months of January to February. Cultivars Pierrot, Tropical, and Success were harvested at three developmental Stages 6-1 (newly opened), 6-2 (spadix 1/2 mature), and 6-3 (spadix 3/4 mature), as defined by Collette (2002). Cultivar Tropical was harvested at five stages (Stages 2 to 6 ) to determine the effect of stage on color formation.

pH measurement. A random sample of five discs from 10 discs $\left(50 \mathrm{~mm}^{2}\right)$ obtained from each spathe using a cork borer was used as an experimental unit in the studies. The epidermal peels from the adaxial surface of these discs were obtained, ground in $0.4-\mathrm{mL}$ Millipore water, pipetted into an enzyme-linked immunosorbent assay plate, and the $\mathrm{pH}$ determined using a $\mathrm{pH}$ meter (Corning $\mathrm{pH}$ meter Model 220; Vernon Hills, IL) carrying a general purpose combination electrode (Griesbach, 2005; Katsumoto et al., 2007).

Color determination. Color values based on the CIE L*a*b* system for the various spathe colors of cultivars were determined using the Chroma Meter CM-200b (Minolta ${ }^{\circledR}$ Company Ltd., Tokyo, Japan). In this system, "L" refers to lightness, whereas " $a$ " and " $b$ " represent the color opponent dimensions. The equipment was calibrated against a white Minolta ${ }^{\circledR}$ Calibration plate before use. Five random measurements were made per spathe. Each cultivar was represented by three spathes.

Experimentation. In the first experiment, 17 cultivars belonging to the white (six), orange (five), and red groups (six) were evaluated for the vacuolar $\mathrm{pH}$. Each cultivar was replicated five times with each replicate represented by a single spathe. The white group consisted of white (three: 'Cuba', 'Pierrot', 'Cotopaxy') and green (three: 'Midori', 'Pistache', 'KAIRI709') spathes, both of which lack anthocyanins (Williams et al., 1981). The orange group consists of coral cultivars (two: 'Venus', 'KAIRI899') and orange cultivars (three: 'Hawaii', 'KAIRI3827', 'KAIRI1767'), both of which contain pelargonidin 3-rutinoside but in different quantities (Iwata et al., 1979). The red group consists of pink (three: 'Spirit', 'Lydia', 'Rosa') and red (three: 'Mirjam', 'Success', 'Tropical') cultivars, both of which contain mainly cyanidin 3-rutinoside but at different levels (Iwata et al., 1979).

The effect of developmental stage of the spathe on $\mathrm{pH}$ was determined in three anthurium cultivars (Pierrot, Success, and Tropical) in Expt. 2 at three stages, as described. The nine treatment combinations were arranged in a factorial structure and were replicated five times. Peeling, extraction, and $\mathrm{pH}$ measurements were carried out as described. In a separate study, the chromospectral parameters were investigated in anthurium cut flowers from Stage 2 to Stage 6 to investigate the effect of developmental stage on color formation.

In the third experiment, leaf discs were obtained from the tip of the spathe versus the base of the spathe in five cultivars representing four spathe colors (two red, one pink, one orange, and one white) to determine the effect of tissue maturity on $\mathrm{pH}$. The experiment was replicated five times.

In the fourth experiment, epidermal peels from three discs each from the abaxial and adaxial surfaces were investigated with five replications in two cultivars (Tropical, Sonata) as described.

In the fifth experiment, three cultivars (President, Senator, and KAIRI3674) with "obake" (bicolored) spathes were used. These cultivars produce bicolored spathes with various anthocyanins at the center of the spathe and no anthocyanins at the periphery. 'President' and 'KAIRI3674' have a dark pink center, whereas 'Senator' has a coral center. In this study, the central pigmented portion was represented by five discs $\left(50 \mathrm{~mm}^{2}\right)$ and the anthocyaninless peripheral regions represented by five discs. The epidermal peels from the adaxial surface for each region were extracted and $\mathrm{pH}$ measurement taken as described.

In the last experiment, changes to spathe $\mathrm{pH}$ were monitored in four cultivars (Pierrot, Mirjam, Success, Tropical) after harvest at $0 \mathrm{~d}$ after picking (DAP), 8 DAP, 16 DAP, 24 DAP, and 32 DAP. The 16 combinations were replicated five times in a completely randomized design. Cut flowers with no scratches, no deformities, and straight peduncles were harvested at the $3 / 4$ mature stage of the spadix (Kamemoto, 1962). Twenty-five cut flowers per cultivar were harvested and brought to the laboratory in a cooler. The experiment was conducted in sterile, $250-\mathrm{mL}$ measuring cylinders in a laboratory $(11 \mathrm{~h}$ white fluorescent light; $23.8^{\circ} \mathrm{C} ; 73.5 \%$ relative humidity). Each cylinder contained five cut flowers placed in $210 \mathrm{~mL}$ of sterile distilled water and was covered with a cellophane wrap to prevent evaporation. Before placing the cut flowers into the cylinder, the base of the peduncles was cut under water at an angle of $45^{\circ}$ using a sterile scalpel.

Data analysis. Data on $\mathrm{pH}$ as well as color $(\mathrm{L} * \mathrm{a} * \mathrm{~b} *$ ) were analyzed using NCSS (NCSS, 2001, Kaysville, UT). The relationship between color intensity and $\mathrm{pH}$ was investigated using
Pearson's product moment correlation coefficient or regression analysis (NCSS, 2001).

\section{Results}

There were significant $(P<0.05)$ differences in $\mathrm{pH}$ between the various color groups (Table 1) with the highest $\mathrm{pH}$ recorded for green-spathed cultivars followed by white, coral, pinks/reds, and orange, in that order. There was no significant difference $(P>0.05)$ between red-and pink-spathed cultivar groups. Cultivar differences in vacuolar $\mathrm{pH}$ within the various colors were significant $(P<0.05)$ for green, coral, red, and pink (Table 1), but were not as large as between colors.

Chromospectral analysis, apart from showing expected differences between the various color groups, also showed significant $(P<0.05)$ differences in the $\mathrm{L}^{*} \mathrm{a} * \mathrm{~b} *$ space parameters among cultivars (Table 1). Among the red-spathed cultivars, 'Tropical' had a significantly higher $\mathrm{pH}$ value $(P<0.05)$ compared with 'Mirjam' and 'Success' with correspondingly higher $\mathrm{L}^{*}$ and $\mathrm{b}^{*}$ values $(P<0.05)$ (Table 1). Among the pink-spathed cultivars, 'Lydia' had a significantly higher $\mathrm{pH}$ value $(P<0.05)$ than 'Rosa', which in turn had a significantly higher $\mathrm{pH}$ value $(P<0.05)$ than 'Spirit'. Again, the $\mathrm{L}^{*}$ values reflected closely the $\mathrm{pH}$ (Table 1). Although $b^{*}$ values were significant between cultivars, they did not correspond to the $\mathrm{pH}$ values (Table 1 ). Neither the $\mathrm{pH}$ nor the $\mathrm{L}^{*} \mathrm{a} * \mathrm{~b} *$ values were significant among the orange-spathed cultivars. Among the coralcolored cultivars, 'Venus' with the higher L* value had a significantly higher $\mathrm{pH}$ than 'KAIRI899' with a lower L* value. Among the whites, there were significant differences $(P<0.001)$ among $\mathrm{L}^{*} \mathrm{~b}^{*}$ with $\mathrm{L}^{*}$ values being positively correlated to $\mathrm{pH}(r=0.97)$. Among the green cultivars, cultivar KAIRI709 had the highest $\mathrm{L}^{*}$ value followed by 'Pistache' and 'Midori', in that order. Although all the $\mathrm{L} * a * b *$ color space parameters were significantly different among the green-spathed cultivars, none were significantly correlated to $\mathrm{pH}$.

Table 1. The vacuolar $\mathrm{pH}$ values and chromospectrometric measurements for 17 cultivars of Anthurium andraeanum (Hort.).

\begin{tabular}{|c|c|c|c|c|c|c|}
\hline \multirow[b]{2}{*}{ Color group ${ }^{z}$} & \multirow[b]{2}{*}{ Cultivar ${ }^{\mathrm{y}}$} & \multirow{2}{*}{$\begin{array}{l}\text { Epidermal } \\
\text { peel } \mathrm{pH}\end{array}$} & \multicolumn{3}{|c|}{ Chromospectrometric measurements } & \multirow{2}{*}{$\begin{array}{c}\text { Mean pH } \\
\text { color group }\end{array}$} \\
\hline & & & $\mathrm{L}^{*}$ & $a^{*}$ & $b^{*}$ & \\
\hline \multirow[t]{3}{*}{ White } & Cuba & 5.51 & 84.1 & -2.2 & 19.9 & 5.57 \\
\hline & Pierrot & 5.57 & 88.5 & -2.1 & 10.2 & \\
\hline & Cotopaxy & 5.56 & 89.7 & -2.5 & 11.7 & \\
\hline \multirow[t]{3}{*}{ Green } & Midori & 5.50 & 55.2 & -17.7 & 31.4 & 5.74 \\
\hline & Pistache & 5.78 & 61.2 & -9.7 & 27.1 & \\
\hline & KAIRI 709 & 5.94 & 68.3 & -18.1 & 39.6 & \\
\hline \multirow[t]{2}{*}{ Coral } & KAIRI 899 & 5.26 & 60.5 & 44.5 & 28.2 & 5.38 \\
\hline & Venus & 5.49 & 64.8 & 43.0 & 26.3 & \\
\hline \multirow[t]{3}{*}{ Orange } & KAIRI 3827 & 4.50 & 52.5 & 54.8 & 37.2 & 4.51 \\
\hline & KAIRI 1767 & 4.53 & 53.7 & 48.5 & 30.9 & \\
\hline & Hawaii & 4.49 & 51.7 & 53.5 & 35.1 & \\
\hline \multirow[t]{3}{*}{ Pink } & Spirit & 5.02 & 63.7 & 32.6 & 14.0 & 5.20 \\
\hline & Rosa & 5.20 & 69.7 & 32.7 & 12.4 & \\
\hline & Lydia & 5.40 & 74.6 & 23.4 & 15.4 & \\
\hline \multirow[t]{4}{*}{ Red } & Tropical & 5.31 & 41.8 & 50.4 & 22.4 & 5.09 \\
\hline & Success & 4.92 & 38.8 & 48.7 & 19.0 & \\
\hline & Mirjam & 5.07 & 37.2 & 46.7 & 19.2 & \\
\hline & SE & 0.051 & 1.43 & 2.14 & 0.84 & 0.041 \\
\hline
\end{tabular}

z,y The effect of color group and cultivar were significant on vacuolar $\mathrm{pH}$ and $\mathrm{L} * \mathrm{a} * \mathrm{~b} *$. 
The relationship between color space parameters $a^{*}$ and $b^{*}$ (Fig. 1) showed that various anthocyanin-based color groups could be clearly distinguished. Pinks had low a* and $b^{*}$ values, whereas reds have low a* but high $b^{*}$ values. The corals and oranges had above average $a^{*}$ and $b^{*}$ values and formed a continuum with the corals at the lower end of the continuum. These results indicated that apart from color intensity measured by $\mathrm{L}^{*}$, which was used to distinguish between red versus pink and orange versus coral, there were differences in $\mathrm{a}^{*}$ and $\mathrm{b}^{*}$ among the color groups.

The effect of spathe developmental stage (6-1, 6-2, and 6-3) significantly influenced $\mathrm{pH}(P<0.05)$ in all the three cultivars studied with $\mathrm{pH}$ decreasing from Stage 6-1 to 6-2 but not significantly changing thereafter. The cultivar $\times$ stage interaction was not significant, indicating that the effect of stage of spathe on $\mathrm{pH}$ was independent of the effect of cultivar (Table 2). The effect of cultivar on $\mathrm{pH}$ was again the most profound (F value of 178) with the white-spathed 'Pierrot' $(\mathrm{pH}=5.0)$ having the highest $\mathrm{pH}$ followed by red-spathed cultivars Tropical ( $\mathrm{pH} 4.5)$ and Success (3.7).

The chromospectral data $\left(\mathrm{L}^{*} \mathrm{a} * \mathrm{~b}^{*}\right)$ did not show significant $(P>0.05)$ differences among the three substages within Stage 6 (6-1, 6-2, 6-3), but there was a significant decrease in L* from Stage 3 to Stage 4, which remained relatively constant thereafter up to Stage 6 (Fig. 2). Similarly, a* increased significantly from Stage 3 to Stage 4 but remained relatively constant thereafter (Fig. 2). Color space parameter $\mathrm{b}^{*}$, however, did not show any specific trend with developmental stage (Fig. 2).

Neither the effect of sampling location within the spathe (tip versus base) nor the cultivar $\times$ sampling location interaction were significant $(P>0.05)$ in the six cultivars evaluated. The effect of cultivar differences, however, was highly significant $(P<0.001)$ (data not shown).

Among two cultivars investigated, there was a slight but significantly higher $\mathrm{pH}(P<$ $0.05)$ in the abaxial epidermal peel compared with that in the adaxial epidermal peel in 'Sonata', but this was not observed in 'Tropical' $(P>0.05)$. This accounted for the significant cultivar $\times$ surface interaction $(P<$ 0.01 ) (Table 3). The higher $\mathrm{pH}$ in abaxial cells was reflected in the significantly higher $\mathrm{L}^{*}$ and small $\mathrm{a}^{*}$ and $\mathrm{b}^{*}$ values in 'Sonata'. Although 'Tropical' showed a small but significant increase in L* (not significant a* or $\mathrm{b}^{*}$ ) in the abaxial compared with adaxial data, there was no significant difference in $\mathrm{pH}$. The cultivar effect was significant $(P<0.001)$ with the pink-spathed 'Sonata' ( $\mathrm{pH}$ 5.36) having a higher $\mathrm{pH}$ than the red-spathed 'Tropical' (5.02).

In the obake-spathed cultivars, $\mathrm{pH}$ was always significantly higher $(P<0.001)$ in the green peripheral regions of the spathe compared with the anthocyanin-containing centers (Table 4). The significant cultivar $\times$ treatment interaction indicates that the degree to which the green peripheral regions had a higher $\mathrm{pH}$ varied with cultivars. Difference in $\mathrm{pH}$

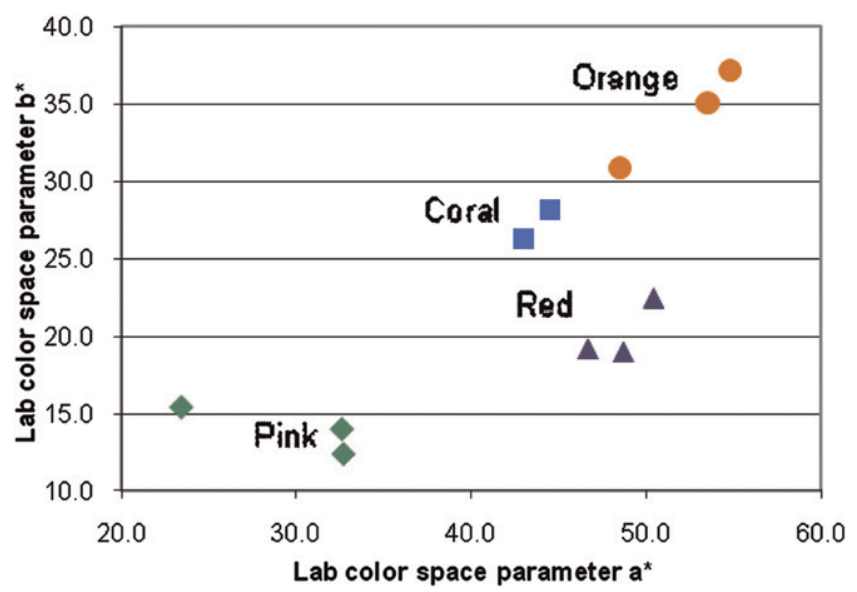

Fig. 1. The relationship between color space parameters a* and $\mathrm{b}^{*}$ in four color groups in Anthurium andraeanum Hort.

Table 2. The vacuolar $\mathrm{pH}$ and chromospectrometric measurements as influenced by developmental stage and cultivar in Anthurium andraeanum Hort.

\begin{tabular}{llccccc}
\hline $\begin{array}{l}\text { Developmental } \\
\text { stage of spathe }\end{array}$ & Cultivar & $\begin{array}{c}\text { Vacuolar } \\
\mathrm{pH}^{\mathrm{z}}\end{array}$ & \multicolumn{2}{c}{ Chromometric measurements $^{\mathrm{y}}$} & \multicolumn{2}{c}{$\begin{array}{c}\text { Mean } \mathrm{pH} \\
\text { stage }\end{array}$} \\
\cline { 5 - 6 } Stage 6-1 & Pierrot & 5.00 & 89.3 & -2.9 & 13.1 & 4.51 \\
& Tropical & 4.65 & 40.2 & 50.4 & 22.6 & \\
Stage 6-2 & Success & 3.89 & 37.3 & 48.3 & 17.5 & \\
& Pierrot & 4.96 & 89.4 & -2.4 & 12.3 & 4.33 \\
& Tropical & 4.42 & 41.6 & 49.3 & 22 & \\
Stage 6-3 & Success & 3.62 & 36.7 & 46.3 & 16.4 & 4.42 \\
& Pierrot & 5.00 & 88.5 & -2.1 & 12.2 & \\
SE & Tropical & 4.54 & 44.1 & 46.3 & 24.2 & \\
& Success & 3.71 & 37.6 & 46.1 & 18.9 & 0.047 \\
\hline
\end{tabular}

zThe cultivar and spathe developmental stage significantly affected $\mathrm{pH}$ at $P<0.05$ and $P<0.001$, respectively, but the interaction was not significant.

${ }^{\mathrm{y}}$ The effect of cultivar, developmental stage, and interaction were significant for $\mathrm{L}^{*} \mathrm{a} * \mathrm{~b}^{*}$.

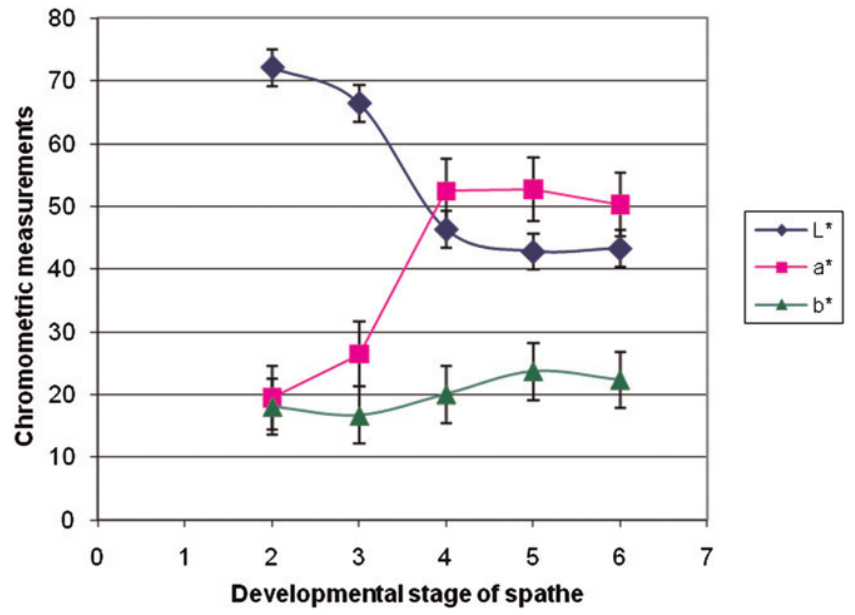

Fig. 2. Spathe chromospectrometric space parameters $L^{*} a^{*} b^{*}$ as affected by spathe developmental stage (the bars represent \pm least significant difference values).

between the green and pigmented centers was particularly high for 'Senator' with a coral center compared with 'President' and 'KAIRI3674', which had a dark pink center (Table 4).

Effects of cultivar, post-harvest age, and the interaction between cultivar and postharvest age on $\mathrm{pH}$ were highly significant $(P<0.001)$. Effect of cultivar on $\mathrm{pH}$ was the highest (highest $\mathrm{F}$ value). The white-spathed 'Pierrot' had a significantly higher $(P<$ $0.001) \mathrm{pH}(5.61)$ than the red-spathed 'Tropical', 'Success', and 'Mirjam' (average 4.8). The $\mathrm{pH}$ increased from 4.96 at picking to 5.27 , 24 DAP. Unlike the other cultivars, 'Success' did not show significant variation in $\mathrm{pH}$ with age, which would have accounted for the significant cultivar $\times$ age interaction (Table 5). 
Table 3. The effect of the sampling location within a spathe (center versus lobe) on $\mathrm{pH}$ and chromospectrometric measurements in three obake cultivars of anthurium.

\begin{tabular}{llccccc}
\hline Cultivar & $\begin{array}{l}\text { Sampling } \\
\text { location }\end{array}$ & $\begin{array}{c}\text { Vacuolar } \\
\mathrm{pH}^{\mathrm{z}}\end{array}$ & \multicolumn{2}{c}{ Chromometric measurements $^{\mathrm{y}}$} & $\begin{array}{c}\text { Mean } \mathrm{pH} \\
\text { cultivar }\end{array}$ \\
\cline { 5 - 7 } President & Green & 5.25 & 46.1 & -15.6 & 26.3 & 5.05 \\
& dark pink & 4.87 & 58.3 & 36.5 & 16.2 & \\
Senator & Green & 5.22 & 49.7 & -17.2 & 32.7 & 4.84 \\
& Coral & 4.45 & 76.9 & 18.3 & 20.8 & \\
KAIRI3674 & Green & 4.84 & $-\mathrm{C}^{*}$ & - & - & 4.66 \\
& dark pink & 4.50 & - & - & - & \\
SE & & 0.047 & 2.1 & 2.6 & 1.7 & 0.030 \\
\hline
\end{tabular}

${ }^{2}$ The cultivar and spathe location effects significantly affected $\mathrm{pH}$ at $P<0.001$ with significant interaction $(P<0.001)$.

${ }^{y}$ The effect of cultivar, sampling location, and interaction were significant for $\mathrm{L}^{*} \mathrm{a} * \mathrm{~b} *$.

${ }^{x}$ Adequate blooms were not available for chromospectrometric measurements.

Table 4. The effect of the sampling of spathe surfaces (adaxial versus abaxial) on $\mathrm{pH}$ and chromospectrometric measurements in two cultivars of anthurium.

\begin{tabular}{|c|c|c|c|c|c|c|}
\hline \multirow[b]{2}{*}{ Cultivar } & \multirow{2}{*}{$\begin{array}{c}\text { Sampling } \\
\text { surfaces }\end{array}$} & \multirow{2}{*}{$\begin{array}{c}\text { Vacuolar } \\
\mathrm{pH}^{\mathrm{z}}\end{array}$} & \multicolumn{3}{|c|}{ Chromospectrometric measurements $^{y}$} & \multirow{2}{*}{$\begin{array}{c}\text { Mean } \mathrm{pH} \\
\text { cultivar }\end{array}$} \\
\hline & & & $\mathrm{L}^{*}$ & $a^{*}$ & $\mathrm{~b}^{*}$ & \\
\hline \multirow{2}{*}{ Sonata } & Adaxial & 5.27 & 57.6 & 46.9 & 14.5 & 5.36 \\
\hline & Abaxial & 5.46 & 75.0 & 15.9 & 9.0 & \\
\hline \multirow[t]{2}{*}{ Tropical } & Adaxial & 5.07 & 42.1 & 50.4 & 22.1 & 5.03 \\
\hline & Abaxial & 4.98 & 44.7 & 50.0 & 20.8 & \\
\hline SE & & 0.035 & 0.46 & 1.33 & 0.59 & 0.024 \\
\hline
\end{tabular}

${ }^{2}$ The cultivar and cultivar $\times$ spathe location interaction effects were significant on $\mathrm{pH}$ at $P<0.001$ and $P<$ 0.01 , respectively; but the sampling location effect was not significant.

${ }^{\mathrm{y}}$ The effect of cultivar, sampling location, and interaction were significant for $\mathrm{L}^{*} \mathrm{a} * \mathrm{~b} *$.

Table 5. The effect of time after cut flower harvesting on spathe vacuolar $\mathrm{pH}$ and chromospectrometric measurements in four cultivars of anthurium.

\begin{tabular}{|c|c|c|c|c|c|c|}
\hline \multirow[b]{2}{*}{ Cultivar } & \multirow{2}{*}{$\begin{array}{c}\text { Time after } \\
\text { picking }\end{array}$} & \multirow{2}{*}{$\begin{array}{c}\text { Vacuolar } \\
\mathrm{pH}^{\mathrm{z}}\end{array}$} & \multicolumn{3}{|c|}{ Chromospectrometric measurements $^{y}$} & \multirow{2}{*}{$\begin{array}{l}\text { Mean } \mathrm{pH} \\
\text { cultivar }\end{array}$} \\
\hline & & & $\mathrm{L}^{*}$ & $a^{*}$ & $\mathrm{~b}^{*}$ & \\
\hline \multirow[t]{5}{*}{ Pierrot } & $0 \mathrm{~d}$ & 5.58 & 89.4 & -2.4 & 12.2 & 5.61 \\
\hline & $8 \mathrm{~d}$ & 5.68 & - & - & - & \\
\hline & $16 \mathrm{~d}$ & 5.59 & - & - & - & \\
\hline & $24 \mathrm{~d}$ & 5.74 & 41.6 & -2.9 & 12.9 & \\
\hline & $32 \mathrm{~d}$ & 5.46 & - & - & - & \\
\hline \multirow[t]{5}{*}{ Tropical } & $0 \mathrm{~d}$ & 4.87 & 36.7 & 49.3 & 22.0 & 5.06 \\
\hline & $8 \mathrm{~d}$ & 5.00 & - & - & - & \\
\hline & $16 \mathrm{~d}$ & 5.10 & - & - & - & \\
\hline & $24 \mathrm{~d}$ & 5.28 & 90.3 & 34.5 & 1.5 & \\
\hline & $32 \mathrm{~d}$ & - & - & - & - & \\
\hline \multirow[t]{5}{*}{ Success } & $0 \mathrm{~d}$ & 4.58 & 42.2 & 46.3 & 16.4 & 4.72 \\
\hline & $8 \mathrm{~d}$ & 4.73 & - & - & - & \\
\hline & $16 \mathrm{~d}$ & 4.75 & - & - & - & \\
\hline & $24 \mathrm{~d}$ & 4.78 & 36.6 & 44.5 & 16.0 & \\
\hline & $32 \mathrm{~d}$ & 4.77 & - & - & - & \\
\hline \multirow[t]{5}{*}{ Mirjam } & $0 \mathrm{~d}$ & 4.74 & 38.8 & 43.2 & 17.5 & 4.89 \\
\hline & $8 \mathrm{~d}$ & 4.80 & - & - & - & \\
\hline & $16 \mathrm{~d}$ & 4.77 & - & - & - & \\
\hline & $24 \mathrm{~d}$ & 4.84 & $-^{x}$ & - & - & \\
\hline & $32 \mathrm{~d}$ & 5.28 & - & - & - & \\
\hline SE & & 0.055 & 0.51 & 0.45 & 0.37 & 0.025 \\
\hline
\end{tabular}

${ }^{\mathrm{z}}$ The cultivar and time of picking significantly affected $\mathrm{pH}$ at $P<0.001$ with significant interaction $(P<$ $0.001)$.

${ }^{y}$ The effect of cultivar and interaction between cultivar $\times$ time of picking were significant for $L^{*} a * b *$. Time after picking was significant for $\mathrm{a}$ * and $\mathrm{b}$ * only. Only 'Pierrot', 'Tropical', and 'Success' were included in the analysis.

${ }^{x}$ Data on $\mathrm{L}^{*} \mathrm{a}{ }^{*} \mathrm{~b} *$ were not collected.

Chromospectral data obtained at 0 DAP and 24 DAP did not show significant $(P>$ $0.05)$ changes in $L^{*}$ in 'Success' and 'Mirjam' but showed changes in opposite directions in 'Pierrot' and 'Tropical', accounting for the significant interaction. With respect to $\mathrm{a}^{*}$ and $\mathrm{b}^{*}$, not only were there significant $(P<$ 0.05 ) differences with age, but there was a significant cultivar $\times$ age interaction. For instance, although there were significant reductions in $\mathrm{a}^{*}$ and $\mathrm{b}^{*}$ values in 'Tropical' with ception of bracts of Poinsettia (Stewart et al., 1975). This is the first study of $\mathrm{pH}$ in anthurium spathe, a modified leaf. The $\mathrm{pH}$ measurements among the 23 cultivars studied varied from 4.6 to 5.9 in the epidermal peels of spathe, where the pigments are concentrated (Ehrenberger and Kuehnle, 2003). The $\mathrm{pH}$ values suitable for developing blue color in floral tissues were found to be above 5.25 in roses (Rosa hybrida) (Katsumoto et al., 2007), from 6.6 to 7.7 in morning glory (Ipomoea tricolor) (Yoshida et al., 1995), 5.8 to 6.4 in Petunia hybrida (Griesbach, 1996), 4.9 to 5.7 in Phalaenopsis pulcherrima (Griesbach, 2005), and above 4.1 in Hydrangea macrophylla (Yoshida et al., 2003). The values found in this study were within the $\mathrm{pH}$ range suitable for blues, identified in three species.

The relationship among various spathe colors and $\mathrm{pH}$ was the most striking with the green and white cultivars having the highest average $\mathrm{pH}$ (5.65). They were followed by corals (5.38), pinks (5.20), reds (5.10), and oranges (4.50). The differences were significant among color groups, except for differences between reds and pink. Within colors, cultivars with lighter shade (higher $\mathrm{L}^{*}$ ) had a higher $\mathrm{pH}$ than those with a darker shade. Iwata et al. (1985) demonstrated that coral and pink spathes had lower levels of anthocyanins compared with orange and red spathes. These data suggest that $\mathrm{pH}$ is associated with not only the anthocyanin present, but also its concentration.

Evidence of the presence of anthocyanins is associated with a low $\mathrm{pH}$ coming from the experiment involving obake (bicolored) anthurium spathes, in which the variously colored segments of the spathe of the same genotype had large divergent $\mathrm{pH}$ values. The green and white portions of the spathe consistently had a higher $\mathrm{pH}$ than the colored sections of the spathe. This is in conformity with studies in Fuchsia, in which epidermal $\mathrm{pH}$ values of differently colored parts of the same flower were dissimilar (Stewart et al., 1975).

Similarly, supporting evidence for the effect of concentration of anthocyanins on vacuolar $\mathrm{pH}$ comes from the evaluation of two cultivars, Tropical with the same level of pigmentation at the abaxial and adaxial surface and Sonata with a much lighter pigmentation in the abaxial than the adaxial surface. 'Tropical' showed no significant differences in $\mathrm{pH}$ between the abaxial and adaxial peels, whereas with 'Sonata', the difference in $\mathrm{pH}$ was significant.

Studies in Petunia hybrida (Quattrocchio et al., 2006; Spelt et al., 2002) have shown that AN1 coding for a basic helix-loop-helix protein has a pleiotropic effect controlling, in addition to anthocyanin synthesis by regulating dihydro flavonol 4-reductase (DFR), also controls acidification of vacuoles and seed coat morphogenesis. They also showed that different functions of the anl gene could be abolished by mutating different domains of the gene. Later work by Quattrocchio et al. (2006) showed that AN1 protein can have differential effects through interacting with different Myb proteins. These results indicate 
that the higher $\mathrm{pH}$ in whites and greens observed in this study could be the result of pleiotropic effects of controlling elements on anthocyanin biosynthesis. Alternately, Figueiredo et al. (1999) showed that malonic acid residues present in many anthocyanins appear to result in color stabilization by providing a lower $\mathrm{pH}$ in the vacuolar solution, which may account for differences among color groups.

There were significant differences in $\mathrm{pH}$ between cultivars within each color category. Cultivar differences within each color category varied between $1 \%$ to $8 \%$, depending on the color group, indicating the importance of screening a large number of cultivars within each color group to identify those with high $\mathrm{pH}$ for use in bioengineering of blue flowers as suggested by Griesbach (2005) for orchids. Similarly, considerable within cultivar variation in $\mathrm{pH}$ was seen in roses. A total of 169 cultivars was screened for $\mathrm{pH}$ and flavonoid content in roses with six cultivars ( $\mathrm{pH}$ values varying from 4.85 to 5.46 ) being selected as candidates for transformation (Katsumoto et al., 2007).

There was a significant decrease in $\mathrm{pH}$ between the developmental Stages 6-1 to 6-2, which remained constant through Stage 6-3. However, chromospectral analysis showed a significant decrease in $\mathrm{L}^{*}$ and increase in $a^{*}$ up to Stage 4, beyond which the differences were not significant. These results in combination suggest that the decrease in $\mathrm{pH}$ from Stage 6-1 to 6-2 may reflect that $\mathrm{pH}$ changes with development that may be associated with factors other than anthocyanin concentration. In addition, although the development age of the base is regarded as older than the tip of the spathe (Hartmann et al., 2001), there were no significant $\mathrm{pH}$ differences between tip versus base in any of the cultivars tested.

The $\mathrm{pH}$ of spathe increased with time after harvest of 'Tropical' and 'Mirjam' but not 'Success'. Furthermore, the change in $\mathrm{pH}$ was not associated with $\mathrm{L}^{*}$ but rather with changes in $a^{*}$ and $b^{*}$, which mirror changes in color rather than intensity. Loss of vase life in anthurium is as a result of loss of spathe glossiness, spathe, and spadix browning and spathe bluing (Elibox and Umaharan, 2008b; Paull, 1982). Spathe bluing is attributed to an increase in $\mathrm{pH}$ from 5.2 to 5.6 caused by an increase in ammonium ions resulting from protein breakdown (Paull et al., 1985).

In roses, blue color was obtained (Katsumoto et al., 2007) by silencing the endogenous DFR and expression of iris DFR and viola $\mathrm{F}^{\prime} 5^{\prime} \mathrm{H}$ into a high $\mathrm{pH}$, high flavones genetic background. Prior studies on anthurium (Collette et al., 2004; Elibox and Umaharan, 2008a) that elucidate the genetic control of anthocyanin biosynthesis in spathe tissue paves the way for engineering blue hues. Nevertheless, it is first important to identify an appropriate $\mathrm{pH}$ background. This study suggests that corals, which have the highest $\mathrm{pH}$ among the color groups, may be best suited as targets for transformation, because they contain lower levels of $\mathrm{pH}$-reducing anthocyanins
(Iwata et al., 1985). Alternately, red anthurium should be screened for genotypes with high $\mathrm{pH}$ values.

\section{Literature Cited}

Asen, S. and H.W. Siegelman. 1957. Effect of aluminium on absorption spectra of the anthocyanin and flavonols from sepals of Hydrangea macrophylla var. Merveille. Proc. Amer. Soc. Hort. Sci. 70:478-481.

Collette, V.E. 2002. A molecular analysis of flower color development in an ornamental monocot, Anthurium andraeanum. $\mathrm{PhD}$ diss., Massey University, Palmerston North, New Zealand.

Collette, V.E., P.E. Jameson, K.E. Schwinn, P Umaharan, and K.M. Davies. 2004. Temporal and spatial expression of flavonoid biosynthetic genes in flowers of Anthurium andraeanum. Physiol. Plant. 122:297-304.

Davis, K.M. and K.E. Schwinn. 1997. Flower colour, p. 259-294. In: Geneve, R.L., J.E. Preece, and S.A. Merkle (eds.). Biotechnology of ornamental plants. CAB International, Oxon, UK.

Ehrenberger, J. and A.R. Kuehnle. 2003. Enhanced histological technique for observation of spathe pigmentation in anthurium species and hybrids. Aroideana 26:120-124.

Elibox, W. and P. Umaharan. 2008a. Inheritance of major spathe colours in Anthurium andraeanum Hort. is determined by three major genes. HortScience 43:787-791.

Elibox, W. and P. Umaharan. 2008b. Morphophysiological characteristics associated with vase life of cut flowers of anthurium. HortScience 43:825-831.

Figueiredo, P., F. George, F. Tatsuzawa, K. Toki, N. Saito, and R. Brouillard. 1999. New features of intramolecular copigmentation by acylated anthocyanins. Phytochemistry 51:125-132.

Goto, T. and T. Kondo. 1991. Structure and molecular stacking of anthocyanins-Flower color variations. Angew. Chem. Int. Ed. Engl. 30:1733.

Griesbach, R.J. 1996. The inheritance of flower color in Petunia hybrida Vllm. J. Hered. 87: 241-245.

Griesbach, R.J. 1997. Biochemical basis for the blue flower color mutations in Doritis pulcherrima and Phalaenopsis violacea. Lindleyana 12:64-71.

Griesbach, R.J. 2005. A scientific approach to breeding blue orchids: Exploring new frontiers in search of elusive flower colors. Orchids (W. Palm Beach, Fla.) 74:376-379.

Harborne, J.B. 1988. The flavonoids: Recent advances, p. 299-343. In: Goodwin, T.W. (ed.). Plant pigments. Academic Press Ltd., London, UK.

Hartmann, H.T., D.E. Kester, F.T. Davies Jr., and R.L. Geneve. 2001. Hartmann and Kester's plant propagation: Principles and practices. 7th Ed. Prentice Hall, Englewood Cliffs, NJ.

Higaki T., H.P. Rasmusan, and W.J. Carpenter. 1984. A study of some morphological and anatomical aspects of Anthurium andraeanum Lind. HITAHR Research Series, University of Hawaii 030:1-12.

Iwata, R.Y., C.S. Tang, and H. Kamemoto. 1979. Anthocyanins of Anthurium andraeanum Lind. J. Amer. Soc. Hort. Sci. 104:464-466.

Iwata, R.Y., C.S. Tang, and H. Kamemoto. 1985. Concentration of anthocyanins affecting spathe color in anthuriums. J. Amer. Soc. Hort. Sci. 110: 383-385.

Kamemoto, H. 1962. Some factors affecting the keeping quality of Anthurium flowers. Hawaii Farm Science 11:2-4.
Kamemoto, H. and A.R. Kuehnle. 1996. Breeding anthuriums in Hawaii. Univ. Hawaii Press, Honolulu, HI.

Katsumoto, Y., M. Fukuchi-Mizutani, Y. Kukui, F. Brugliera, T.A. Holton, M. Karan, N. Nakamura, K. Yonekura-Sakakibara, J. Togami, A. Pigeaire, G.-Q. Tao, N.S. Nehra, C.-Y. Lu, B.K. Dyson, S. Tsuda, T. Ashikari, T. Kusumi, J.G. Mason, and Y. Tanaka. 2007. Engineering of the rose flavonoid biosynthetic pathway successfully generated blue-hued flowers accumulating delphinidin. Plant Cell Physiol. 48: 1589-1600.

Nieuwhof, M., J.P. van Eijk, and W. Elkelboom. 1989. Relation between flower color and pigment composition of tulip (Tulipa L.). Neth. J. Agr. Sci. 37:365-370.

Noda, K.-I., B.J. Glover, P. Linstead, and C. Martin. 1994. Flower colour and intensity depends on specialized cell shape controlled by a Myb-related transcription factor. Nature 369: 661-664.

Paull, R.E. 1982. Anthurium (Anthurium andraeanum André) vaselife evaluation criteria. HortScience 17:606-607.

Paull, R.E., N.J. Chen, and J. Deputy. 1985. Physiological changes associated with senescence of cut anthurium flowers. J. Amer. Soc. Hort. Sci. 110:156-162.

Quattrocchio, F., W. Verweij, A. Kroon, C. Spelt, J. Mol, and R. Koes. 2006. PH4 of Petunia is an R2R3 MYB protein that activities vacuolar acidification through interactions with basichelix-loop-helix transcription factors of the anthocyanin pathway. Plant Cell 18:12741291.

Schijlen, E.G.W.M., C.H.R. de Vos, A.J. van Tunen, and A.G. Bovy. 2004. Modification of flavonoid biosynthesis in crop plants. Phytochemistry 65:2631-2648.

Shoji, K., N. Miki, N. Nakajima, K. Momonoi, C. Kato, and K. Yoshida. 2007. Perianth bottomspecific blue colour development in Tulip cv. Murasakizuisho requires ferric ions. Plant Cell Physiol. 48:243-251.

Spelt, C., F. Quattrocchio, J. Mol, and R. Koes. 2002. Anthocyanin 1 of Petunia controls pigment synthesis, vacuolar $\mathrm{pH}$, and seed coat development by genetically distinct mechanisms. Plant Cell 14:2121-2135.

Stewart, R.N., K.H. Norris, and S. Asen. 1975. Microspectrophotometric measurement of $\mathrm{pH}$ and $\mathrm{pH}$ effect on color of petal epidermal cells. Phytochemistry 14:937-942.

Williams, C.A., J.B. Harborne, and S.J. Mayo. 1981. Anthocyanin pigments and leaf flavonoids in the family Araceae. Phytochemistry 20: 217-234.

Yamaguchi, T., S. Fukada-Tanaka, Y. Inagaki, N. Saito, K. Yonekura-Sakakibara, Y. Tanaka, T. Kusumi, and S. Iida. 2001. Genes encoding the vacuolar $\mathrm{Na}^{+} / \mathrm{H}^{+}$exchanger and flower coloration. Plant Cell Physiol. 42:451-461.

Yoshida, K., M. Kawachi, M. Mori, M. Maeshima, M. Kondo, M. Nishimura, and T. Kondo. 2005. The involvement of tonoplast proton pumps and $\mathrm{Na}^{+}\left(\mathrm{K}^{+}\right) / \mathrm{H}^{+}$exchangers in the change of petal colour during flower opening of morning glory, Ipomoea tricolor cv. Heavenly Blue. Plant Cell Physiol. 46:407-415.

Yoshida, K., T. Kondo, Y. Okazaki, and K. Katou. 1995. Cause of blue petal colour. Nature 373: 291.

Yoshida, K., Y. Toyama-Kato, K. Kameda, and T. Kondo. 2003. Sepal color variation of Hydrangea macrophylla and vacuolar $\mathrm{pH}$ measured with a proton-selective microelectrode. Plant Cell Physiol. 44:262-268. 